\title{
ANALISIS PENDEKATAN STUDI TEKNOLOGI E-BISNIS STUDI KASUS LAZADA.ID
}

\author{
Asep sapruddin \\ 165100081 \\ Fakultas Komputer \\ Asepsapruddin.student@umitra.ac.id
}

\begin{abstract}
Lazada.co.id adalah pusat belanja online yang bisa dilakukan melalui android untuk berbelanja dan berteransaksi. Lazada juga menawarkan berbagai macam jenis produk mulai dari elektronik, buku, mainan anak dan perlengkapan bayi, alat kesehatan dan produk kecantikan, peralatan rumah tangga, dan perlengkapan traveling dan olah raga.
\end{abstract}

Lazada Indonesia didirikan pada tahun 2012 dan merupakan salah satu cabang dari jaringan retail online Lazada.co.id di Asia Tenggara Grup Lazada International di Asia Tenggara terdiri dari Lazada Indonesia, Lazada Malaysia, Lazada Vietnam, Lazada Thailand dan Lazada Filipina.

Jaringan Lazada Asia Tenggara merupakan cabang anak perusahaan jaringan perusahaan Internet Jerman, Rocket Internet.Rocket Internet merupakan perusahaan online yang sukses menciptakan perusahaan perusahaan online inovatif di berbagai belahan dunia.

Di Indonesia dapat di akses melalui World Wide Web Lazada.co.id.

Kata Kunci : Pemasaran, Perdagangan elektronik, strategi pemasaran, promosi penjualan, lazada 


\section{A. PENDAhUluan}

Lazada.co.id adalah pusat belanja online yang menawarkan berbagai macam jenis produk mulai dari elektronik, buku, mainan anak dan perlengkapan bayi, alat kesehatan dan produk kecantikan, peralatan rumah tangga, dan perlengkapan traveling dan olah raga.

Lazada Indonesia didirikan pada tahun 2012 dan merupakan salah satu cabang dari jaringan retail online Lazada.co.id di Asia Tenggara Grup Lazada International di Asia Tenggara terdiri dari Lazada Indonesia, Lazada Malaysia, Lazada Vietnam, Lazada Thailand dan Lazada Filipina.

Jaringan Lazada Asia Tenggara merupakan cabang anak perusahaan jaringan perusahaan Internet Jerman, Rocket Internet.Rocket Internet merupakan perusahaan online yang sukses menciptakan perusahaanperusahaan online inovatif di berbagai belahan dunia.

Berkantor pusat di Berlin, Jerman, proyek yang dimiliki Rocket Internet antara lain Zalando, TopTarif, eDarling, Groupon dan lain sebagainya. Lazada.co.id

Indonesia dapat di akses melalui World Wide Web Lazada.co.id.

di Indonesia sejak beberapa tahun terakhir ini. Berbagai kemudahan dalam berbelanja melalu Internet ini dirasakan oleh pengguna seperti memudahkan dalam pencarian produk, tidak perlu membuang banyak waktu dan tenaga dan banyak lagi kemudahan yang ditawarkan oleh situs-situs online shop. Tentu saja ada pula kelemahan yang terjadi ketika kita berbelanja melalui media online tersebut seperti perbedaan tampilan produk pada website dengan produk yang dikirimkan, lamanya waktu pengiriman, bahkan hingga tidak sampainya barang yang telah dipesan dan dibayarkan. Hal tersebut merupakan beberapa kekhawatiran orang yang muncul ketika berbelanja di situs online. Bagi Lazada.co.id, ini merupakan tantangan untuk meningkatkan kepercayaan dalam berbelanja online. Berdasarkan perhitungan, Lazada.co.id. merupakan situs nomor 9 yang paling sering di akses di Indonesia dan merupakan situs online shop paling populer dan sering diakses oleh

para pengguna Internet di Indonesia dalam perdagangan elektronik (e-commerce) (Alexa, 2016). E-commerce adalah penyebaran, pembelian, penjualan, pemasaran barang dan jasa melalui sistem elektronik, dengan cara transfer dana elektronik (Suyanto, 2003: 10). E-commerce juga 
merupakan bagian dari ebusiness, tetapi cakupan ebusiness lebih luas.

E-commerce pertama kali diperkenalkan tahun 1994. Banyak jurnalis memperkirakan bahwa ecommerce akan menjadi sebuah sektor ekonomi baru yang nantinya berkembang pesat. Kesuksesan Lazada.co.id sampai saat ini didukung dengan sebuah kegiatan pemasaran yang baik sehingga dapat menembus pasar ecommerce di Indonesia yang mempunyai banyak perbedaan budaya. Karakteristik konsumen di Indonesia yang selalu mempertimbangkan nilai dan kegunaan sebuah produk dengan teliti (Soemanagara, 2012: 129), mampu dihadapi oleh Lazada. co.id. Pertumbuhan pesat Lazada.co.id memperlihatkan pangsa pasar e-commerce di Indonesia yang semakin lama semakin berkembang dalam perdagangan melalui media Internet. Perkembangan teknologi informasi terutama Internet, merupakan faktor pendorong perkembangan ecommerce. Internet merupakan jaringan global yang menyatukan jaringan komputer di seluruh dunia, sehingga memungkinkan terjalin-nya komunikasi dan interaksi antara satu dengan yang lain diseluruh dunia. Dengan menghubungkan jaringan komputer perusahaan dengan Internet, perusahaan dapat menjalin hubungan bisnis dengan rekan bisnis atau konsumen secara lebih efisien. Sampai saat ini Internet merupakan infrastruktur yang ideal untuk menjalankan ecommerce, sehingga istilah ecommerce pun menjadi identik dengan menjalankan bisnis di Internet. Dengan jumlah pengguna Internet yang mencapai angka 82 juta orang atau sekitar $30 \%$ dari total penduduk di Indonesia (Surata, 2015), pasar e-commerce menjadi tambang emas yang sangat menggoda bagi sebagian orang yang bisa melihat potensi kedepannya. Pertumbuhan ini didukung dengan data dari Menkominfo yang menyebutkan bahwa nilai transaksi e-commerce pada tahun 2013 mencapai angka Rp130 triliun. Pasar bisn

\section{B. PEMBAHASAN / STUDI} KASUS

Sebagian besar bisnis online lazada Indonesia saat ini dilaksanakan di jaringan digital yang menghubungkan lazada dengan konsumen melalui media website yang terhubung dengan Internet. Internet adalah jaringan komputer yang menghubungkan pengguna di seluruh dunia dengan menghubungkan mereka dengan "penyimpanan informasi" yang sangat besar (Kotler \& Armstrong, 2008: 237). Internet merupakan sebuah media komunikasi pemasaran dimana konsumen dapat berinteraksi dengan toko 
online yang berusaha memberikan penawaran kepada mereka. Konsumen dapat berinteraksi dengan mudah melalui media Internet ini. Mereka dapat secara langsung mengontrol pesanan ataupun permintaan informasi lebih lanjut. Demikian pula yang dilakukan lazada Indonesia untuk dapat menciptakan nilai bagi pelanggan dan membangun hubungan dengan pelanggan melalui Internet yang telah memberikan pemasar dengan cara yang benar-benar baru. Melalui media website, lazada Indonesia memberikan informasi lebih mendalam dan leluasa mengenai bentuk serta manfaat suatu produk. Hal ini lebih menguntungkan pemasar dibandingkan menggunakan media lain dimana pemasar harus mengeluarkan biaya yang cukup besar untuk iklan. Internet mengubah sifat dasar dari standar komunikasi pemasaran seperti periklanan dan promosi penjualan. Dalam hal ini, website serupa fungsinya dengan iklan dan merupakan media penjualan baru karena mampu memberikan informasi, bujukan, mengingatkan konsumen mengenai penawaran produk dan melakukan transaksi perdagangan elektronik (ecommerce). Suyanto (2003) mengemukakan e-commerce merupakan konsep baru yang bisa digambarkan sebagai proses jual beli barang atau jasa pada world wide web Internet atau proses jual beli atau pertukaran produk, jasa dan informasi melalui jaringan informasi termasuk Internet. Dengan kata lain, website dianggap perpaduan antara periklanan dan penjualan langsung karena media ini juga dapat mengajak pengunjungnya dalam sebuah dialog atau interaksi langsung. Model perdagangan elektronik yang dilakukan lazada Indonesia ada 2 klasifikasi yaitu pertama adalah bussiness to consumer (B2C) menjual barang dan jasa secara online kepada konsumen akhir (Kotler \& Armstrong, 2008: 238). Konsumen saat ini hampir bisa membeli segala hal secara online di website lazada Indonesia, mulai dari barang elektronik, pakaian, peralatan memasak, perlengkapan bayi, aksesoris dan lain sebagainya. Kedua, bussiness to bussines (B2B) lazada Indonesia melakukan bisnis online ini bekerjasama dengan perusahaan lain seperti perusahaan elektronik yang akan meluncurkan produk terbaru mereka dan menjualnya melaui lazada Indonesia, kegiatan ini memberikan keuntungan ekonomi terhadap kedua pihak. Dengan menggunakan B2B ini jaringan perdagangan online dapat menjangkau pelanggan bisnis baru, melayani pelanggan lebih efektif, dan meraih efisiensi 
pembelian dan harga yang lebih baik (Kotler \& Armstrong, 2008: 239). Komunikasi lewat media Internet berbeda dengan komunikasi pemasaran media tradisional. Perubahan gaya komunikasi dengan lebih segera, melalui email, dimana terdapat two way interaction antara penjual dan pembeli, waktu pengiriman serta penerimaan informasi oleh keduanya dapat diukur dalam hitungan detik sehingga ada keselarasan komunikasi. Ini merupakan teknologi web 2.0 yang sudah merubah segalanya. Internet saat ini menjadi bersifat interaktif dan dinamis. Seseorang lebih mudah mengekspresikan dirinya, melakukan networking, membentuk komunitas, berkolaborasi, berpartisipasi, dan banyak hal lainnya (Kartajaya, 2008: 6). Era yang disebut oleh Hermawan Kartajaya sebagai Era New Wave (web 2.0) menjadikan manusia memasuki tahap perkembangan menjadi pekerja kreatif. Teknologi mendorong lahirnya kreativitas dan mendorong tumbuhnya partisipasi masyarakat. Di era partisipasi alias Era New Wave Marketing, yang terpenting adalah sebuah akses yang terbentuk melalui jaringan yang saling berbagi dan berinteraksi (Kartajaya, 2008: 156). Interaksi langsung seperti halnya melalui Internet ini membuat proses pemasaran ke konsumen lebih terasa akrab, aktif dan personal. Meskipun demikian, Internet tidak sepenuhnya dapat menjamin hubungan utama antara pengirim dan penerima informasi. Ada beberapa hal yang menentukan efektivitas 69Jurnal Kajian Komunikasi, Volume 4, No. 1, Juni 2016, hlm 64 - 74 pemasaran melalui Internet, yaitu desain dan pengembangan website yang merupakan orientasi utama lazada Indonesia untuk menyampaikan pesan terkait informasi produk yang ingin disampaikan ke konsumen, dan lazada Indonesia tidak spesifik ditujukan pada pasar tertentu, jadi siapa saja bisa memanfaatkannya untuk memperoleh informasi tertentu. Kotler \& Armstrong (2008) menjelaskan bahwa perilaku pembelian konsumen sangat dipengaruhi oleh karakteristik personal. Kebudayaan, kelompok sosial, ekonomi mau- pun faktor psikologis sangat memengaruhi respon mereka terhadap pesan pemasaran. Di sini Internet berperan sebagai media yang dapat menampung berbagai konsumen dengan beragam latar belakang sosial dan kebudayaan. Hal ini menjadi keunggulan bagi lazada Indonesia dengan banyaknya potensial konsumen dari berbagai daerah di Indonesia yang dapat memperluas pemasaran produkproduk yang ditawarkan oleh lazada 
Indonesia melalui website. Lazada Indonesia tidak menentukan segmentasi pasar yang terperinci. Mereka menargetkan pasar konsumen yang menggunakan atau terhubung langsung dengan jaringan Internet siapa pun dan dimana saja melaui media online website. Lazada Indonesia melihat pasar dari 3 faktor diantaranya yaitu lingkungan ekonomi, lingkungan budaya, dan lingkungan teknologi. Dilihat dari lingkungan ekonomi, suatu pasar tentunya memerlukan adanya daya beli. Daya beli yang tersedia dalam suatu perekonomian bergantung pada pendapatan, harga, tabungan dan ketersedian kredit. Pemasar harus dapat memperhatikan dengan cermat trend utama dalam pendapatan dan pola pembelanjaan konsumen (Kotler, 1997: 138). Lazada Indonesia melihat potensi yang besar di Indonesia yang ditunjukan data dari Menkominfo yang menyebutkan bahwa nilai transaksi e-commerce pada tahun 2013 mencapai angka Rp130 triliun. Hal ini merupakan potensi yang besar bagi dunia perdagangan elektronik di Indonesia. Lingkungan budaya menunjukkan bahwa setiap orang memiliki perilaku yang berbeda di masyarakat. Manusia menyerap hampir secara tidak sadar, pandangan dunia yang merumuskan hubungan mereka dengan dirinya sendiri dan sesamanya. Kelompokkelompok yang memiliki nilai yang sama dengan para konsumen akan mempengaruhi mereka dalam pembelian barang (Kotler, 1997: 148). Keanekaragaman budaya, letak geografis, dan karakteristik orang Indonesia memang menentukan ketika melakukan belanja. Tantangan yang dihadapi lazada Indonesia ini mereka bangun kepercayaan untuk melakukan belanja di situs web lazada.co.id dengan meningkatkan fasilitas layanan, ketika orang membeli sebuah produk menginginkan barang tersebut ada terlebih dahulu lazada menyediakan fasilitas cash on delivery, dimana barang yang akan dibeli konsumen langsung diantarkan dan dibayar di tempat dan lazada memfasilitasi mereka yang telah berbelanja online dengan customer service untuk keluhan atau penukaran barang yang rusak saat diterima oleh konsumen. Fasilitas customer service tersedia langsung di website lazada.co.id. Lingkungan teknologi merupakan salah satu kekuatan yang paling besar dalam membentuk hidup manusia adalah teknologi. Perubahan teknologi yang terjadi semakin cepat dan tidak terduga. Para pemasar dituntut untuk mengamati perubahan teknologi yang ada demi mendukung berkembangnya suatu brand (Kotler, 1997: 
140). Perkembangan teknologi saat ini sangat pesat, dengan menggunakan website lazada Indonesia sudah bisa melakukan promosi penjualan dan menfasilitasi konsumen dalam berbelanja online dengan berbagai macam fasilitas pembayaran yang diantaranya menggunakan kartu kredit, bank transfer, Internet banking sebagai media pembayaran dalam melakukan perdagangan elektronik (ecommerce). Jelas ini memudahkan konsumen dalam berbelanja dimana pun mereka berada dan terhubung jaringan Internet dengan menggunaka komputer, tablet atau smartphone yang mereka punya. Peran website lazada Indonesia di sini adalah menyediakan media untuk membantu konsumen yang secara aktif mencari produk kebutuhannya. Di sisi lain, ini merupakan kesempatan bagi lazada Indonesia untuk memberikan deskripsi produk mereka, serta mengajukan penawaran kepada konsumen. Selain itu, lazada Indonesia memfasilitasi website mereka dengan fitur pembayaran yang dapat digunakan oleh konsumen

\section{ID SECURITY} QWTD4452377-ASP-5244107

\section{KESIMPULAN}

Indonesia sejak beberapa tahun terakhir ini. Mendapatkan Berbagai kemudahan dalam berbelanja melalu Internet. Aplikasi lazada ini dirasakan oleh pengguna untuk melakukan perbelanjaan secara online dan memudahkan dalam pencarian produk dan tidak perlu lagi membuang banyak waktu dan tenaga untuk melakukan pembelanjaan dan pencarian produk yang di tuju dan banyak lagi kemudahan yang ditawarkan oleh situssitus online seperti traveloka, bukalapak dan penjualan onlen lainnya.

\section{E. DISKUSI}

Saya bersama teman saya bernama riski rianto menurut riski, lazada adalah tempat pembelanjaan online yang memudahkan dan melancarkan pembelanjaan secara baik dan jelas. Lazada juga dapat memudahkan masyarakat atau oengguna aplikasi untuk belanja secara online. Apapun yang di cari sudah tersedia di dalam aplikasi lazada. 


\section{F. REFERENCE}

[1] O. M. Febriani and A. S. Putra, "Sistem Informasi Monitoring Inventori Barang Pada Balai Riset Standardisasi Industri Bandar Lampung," J. Inform., vol. 13, no. 1, pp. 90-98, 2014.

[2] A. S. Putra, "Paperplain: Execution Fundamental Create Application With Borland Delphi 7.0 University Of Mitra Indonesia," 2018.

[3] A. S. Putra, "2018 Artikel Struktur Data, Audit Dan Jaringan Komputer," 2018.

[4] A. S. Putra, "ALIAS MANAGER USED IN DATABASE DESKTOP STUDI CASE DB DEMOS."

[5] A. S. Putra, "COMPREHENSIVE SET OF PROFESSIONAL FOR DISTRIBUTE COMPUTING."

[6] A. S. Putra, "DATA ORIENTED RECOGNITION IN BORLAND DELPHI 7.0."

[7] A. S. Putra, "EMBARCADERO DELPHI XE 2 IN GPUPOWERED FIREMONKEY APPLICATION."

[8] A. S. Putra, "HAK ATAS KEKAYAAN INTELEKTUAL DALAM DUNIA TEKNOLOGY BERBASIS
REVOLUSI INDUSTRI 4.0."

[9] A. S. Putra, "IMPLEMENTASI PERATURAN

PERUNDANGAN UU. NO 31

TAHUN $2000 \quad$ TENTANG

DESAIN INDUSTRI

BERBASIS INFORMATION TECHNOLOGY."

[10] A. S. Putra, "IMPLEMENTATION OF PARADOX DBASE."

[11] A. S. Putra, "IMPLEMENTATION OF TRADE SECRET CASE STUDY SAMSUNG MOBILE PHONE."

[12] A. S. Putra, "IMPLEMENTATION

PATENT FOR APPLICATION WEB BASED CASE STUDI WWW. PUBLIKLAMPUNG. COM."

[13] A. S. Putra, "IMPLEMENTATION SYSTEM FIRST TO INVENT IN DIGITALLY INDUSTRY."

[14] A. S. Putra, "MANUAL REPORT \& INTEGRATED DEVELOPMENT

ENVIRONMENT BORLAND DELPHI 7.0."

[15] A. S. Putra, "PATENT AS RELEVAN SUPPORT RESEARCH."

[16] A. S. Putra, "PATENT FOR RESEARCH STUDY CASE OF APPLE. Inc."

[17] A. S. Putra, "PATENT PROTECTION FOR APPLICATION INVENT."

[18] A. S. Putra, "QUICK REPORT IN PROGRAMMING."

[19] A. S. Putra, "REVIEW CIRCUIT LAYOUT 
COMPONENT

REQUIREMENT ON ASUS NOTEBOOK."

[20] A. S. Putra, "REVIEW TRADEMARK PATENT FOR INDUSTRIAL TECHNOLOGY BASED 4.0."

[21] A. S. Putra, "TOOLBAR COMPONENT PALLETTE IN OBJECT ORIENTED PROGRAMMING."

[22] A. S. Putra, "WORKING DIRECTORY SET FOR PARADOX 7."

[23] A. S. Putra, "ZQUERY CONNECTION IMPLEMENTED PROGRAMMING STUDI CASE PT. BANK BCA Tbk."

[24] A. S. Putra, D. R. Aryanti, and I. Hartati, "Metode SAW (Simple Additive Weighting) sebagai Sistem Pendukung Keputusan Guru Berprestasi (Studi Kasus: SMK Global Surya)," in Prosiding Seminar Nasional Darmajaya, 2018, vol. 1, no. 1, pp. 85-97.

[25] A. S. Putra and O. M. Febriani, "Knowledge Management Online Application in PDAM Lampung Province," in Prosiding International conference on Information Technology and Business (ICITB), 2018, pp. 181-187.

[26] A. S. Putra, O. M. Febriani, and B. Bachry, "Implementasi Genetic Fuzzy System Untuk Mengidentifikasi Hasil Curian Kendaraan Bermotor Di Polda Lampung," SIMADA (Jurnal Sist. Inf. dan Manaj. Basis Data), vol. 1, no. 1, pp. 21-30, 2018.
[27] A. S. Putra, H. Sukri, and K. Zuhri, "Sistem Monitoring Realtime Jaringan Irigasi Desa (JIDES) Dengan Konsep Jaringan Sensor Nirkabel," IJEIS (Indonesian J. Electron. Instrum. Syst., vol. 8, no. 2, pp. 221-232.

[28] D. P. Sari, O. M. Febriani, and A. S. Putra, "Perancangan Sistem Informasi SDM Berprestasi pada SD Global Surya," in Prosiding Seminar Nasional Darmajaya, 2018, vol. 1, no. 1, pp. 289-294. 